\title{
Long-term effects of tidal restriction on fish assemblages in east Atlantic coastal marshlands
}

\author{
Raquel Moreno-Valcárcel ${ }^{1, *}$, Francisco J. Oliva-Paterna ${ }^{2}$, Stanislao Bevilacqua ${ }^{3}$, \\ Antonio Terlizzi ${ }^{3}$, Carlos Fernández-Delgado ${ }^{1}$
}

\begin{abstract}
${ }^{1}$ Departamento de Zoología, Campus Universitario de Rabanales, Universidad de Córdoba, 14071 Córdoba, Spain ${ }^{2}$ Departamento de Zoología y Antropología Física, Campus de Espinardo, Universidad de Murcia, 30100 Murcia, Spain

${ }^{3}$ Dipartimento di Scienze e Tecnologie Biologiche ed Ambientali, Università del Salento, CoNISMa, 73100 Lecce, Italy
\end{abstract}

\begin{abstract}
Anthropogenic pressures on coastal and estuarine wetlands are causing a decline in their ecological value and resources. The construction of hydraulic infrastructures stopping tidal influxes is among the most important historical and current threats to coastal wetlands. Yet, the potential effects of tidal restriction have been poorly studied in European marshlands. We analysed the long-term effects of tidal restriction on the fish assemblage of Atlantic marshlands. Multivariate and univariate analyses detected significant spatial and temporal differences in the structure and functioning of fish assemblages between an impacted marshland and control sites. Abundance and biomass values in the impacted marshland were 3 to 4 times higher than in controls, and the fish assemblage was dominated by exotic invasive species, while the control marshlands were dominated by native species. Generalist freshwater and estuarine guilds were dominant in the impacted marshland with respect to controls, where guilds were evenly represented. The diversity of feeding mode functional groups in controls was significantly higher than in the impacted marshland, which was strongly characterized by omnivorous species. This study highlights biotic homogenization as one of the main consequences of tidal restriction through the shift from native assemblages of specialized fish species towards assemblages of generalist, cosmopolitan and non-native species.
\end{abstract}

KEY WORDS: After-Control-Impact designs · Biotic homogenization · Doñana National Park • Ecological guilds $\cdot$ Multivariate analysis $\cdot$ Salt marshes $\cdot$ Sluice gates

\section{INTRODUCTION}

Direct human modification is by far the major cause of historical and contemporary coastal wetland loss (Kirwan \& Megonigal 2013). Man-made structures, such as sluice gates or dikes, are frequent elements in estuaries and salt marshes, affecting the tidal processes (Kennish 2001, Gedan et al. 2009) and resulting in variations in surface elevation (Bryant \& Chabreck 1998, Couvillion \& Beck 2013), changes in water and soil quality (Portnoy 1991, Portnoy \& Giblin 1997), replacement of vegetation (Roman et al. 1984, Mora \& Burdick 2013), loss of fish diversity
(Harrington \& Harrington 1982, Pollard \& Hannan 1994, Ritter et al. 2008) and/or alteration patterns of abundance and seasonal recruitment of fish and crustaceans (McGovern \& Wenner 1990, Boys \& Williams 2012). As a consequence, tidal restriction in marshlands may cause regime shifts towards degraded environmental conditions where natural key ecological processes are compromised at different spatial and temporal scales (Nicolas et al. 2010).

Transitional water systems, such as estuaries, coastal lagoons and marshlands, are generally characterized by highly variable physico-chemical conditions. Changes in salinity, dissolved oxygen, temper- 
ature and other abiotic variables (e.g. marine water renewal, nutrient load, sedimentation) lead to composite environmental gradients (Maes et al. 2004, Tagliapietra et al. 2009, Nicolas et al. 2010). Such systems are also strongly influenced by geographical and hydrological factors, along with their particular history of environmental management (Cognetti \& Maltagliati 2008, Gedan et al. 2009, Kirwan \& Megonigal 2013). Although transitional water communities are well adapted to cope with high environmental stress, they exhibit composite patterns of variation at different spatial and temporal scales (Menéndez et al. 2002, Maes et al. 2004, Nicolas et al. 2010, Bevilacqua et al. 2015). The complex interplay among abiotic, biological and anthropogenic factors makes it difficult to quantify the human impacts in these environments (e.g. the estuarine quality paradox sensu Elliott \& Quintino 2007).

In such contexts, beyond 'Before-After-ControlImpact' (BACI) designs (Underwood 1991, 1992, 1994), and subsequent adaptations in the absence of 'Before' data (i.e. ACI designs, Glasby 1997), represent the most powerful approach for impact assessment that have been applied successfully in detecting changes to coastal communities. These assessed changes are normally caused by several sources of anthropogenic disturbance, such as sewage discharge (Archambault et al. 2001, Terlizzi et al. 2005), thermal pollution (Lardicci et al. 1999), coastal development (Glasby 1997, Benedetti-Cecchi \& Osio 2007) and oil spills (Queiroz et al. 2006).

Fish assemblages have been recognized as good indicators for environmental impact assessment and monitoring of wetlands (Whitfield \& Elliott 2002). Specifically, the use of ecological guilds, which inform on structure and function of the fish assemblage, have become a popular tool for assessing and predicting community changes in aquatic ecosystems (Pérez-Domínguez et al. 2012). In contrast to the use of taxonomic structure, the ecological guild approach integrates information about the species' use of the estuary as nursery and feeding habitats, migratory routes and refuge habitats (Elliott et al. 2007, Pérez-Domínguez et al. 2012). Alterations in the expected guild patterns have been linked to habitat modifications and environmental effects in several studies (see Pérez-Domínguez et al. 2012 for review). Many studies have suggested that the guild approach may provide valuable information on the ecological status of transitional water bodies (Lobry et al. 2003, Franco et al. 2008). Moreover, the functional approach may help to fill important gaps in the understanding of mechanisms underlying global change and habitat degradation, which have been traditionally studied by mainly focussing on taxonomic groups (Olden 2006).

Tidal restrictions have been among the main human-driven hydrological alterations in the marshes of the Atlantic Coast of North America (Crain et al. 2009, Eberhardt et al. 2011, Dibble \& Meyerson 2012). However, research of human modifications to marshlands in Europe has focussed mostly on embankment and land claim (Davy et al. 2009), and, to our knowledge, our study is the first investigation of the effects of tidal restriction on fish communities in European marshes. We assessed the putatively longterm impact on the structure and functioning of fish assemblages caused by tidal restriction in marshlands from the Atlantic coast of the Iberian Peninsula (SW Europe). Specifically, we tested the null hypothesis of no differences in fish assemblages between 1 tidally restricted marshland and 3 non-restricted marshlands located in the same biogeographical area. This study provides baseline information on potential consequences to fish communities that is still lacking in the European environmental context, and that may be valuable for future research and management plans.

\section{MATERIALS AND METHODS}

\section{Study area, experimental design and sampling methods}

The study area was located in the northern sector of the Gulf of Cadiz, along the south-western coast of the Iberian Peninsula (Atlantic Ocean; Fig. 1). This sector of the coast (approximately $145 \mathrm{~km}$ long) is mainly composed of sandy beaches interrupted by the presence of estuarine mouths of the Guadiana, Piedras, Tinto-Odiel and Guadalquivir Rivers. The tidal regime is mesotidal with a mean range around $3 \mathrm{~m}$, and all of these estuarine systems are tidally dominated and well mixed during low river flow periods (Díez-Minguito et al. 2012). The morphodynamic factors dominant in the area favoured the development of broad littoral lowlands, mostly sheltered by large spits, where intertidal flats and saltand freshwater marshes extend several kilometres inland (Rodríguez-Ramírez et al. 2008).

The lower stretch of the Guadalquivir River flows through the Doñana marshland, a remainder of the Guadalquivir marshes (Bayán-Jardín 2006). In addition to transforming land uses and channeling water courses, intertidal creeks connecting the natural marshland of the Doñana National Park with the 


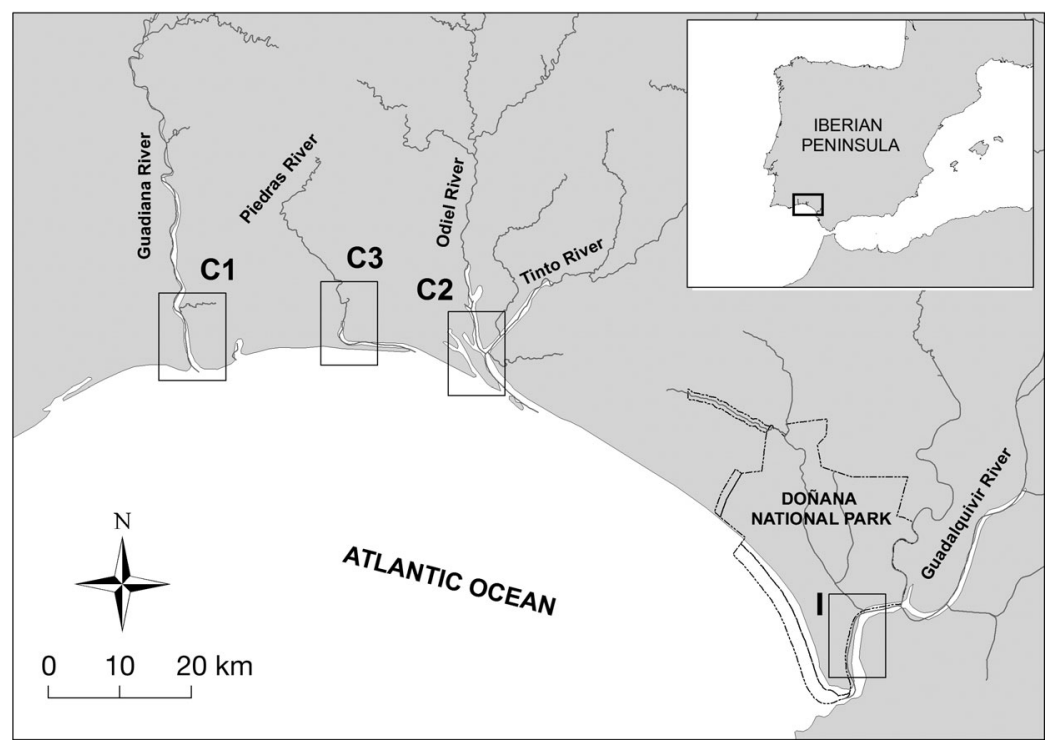

Fig. 1. Investigated marshlands in southwestern Spain. Control sites: C1, Guadiana; C2, Tinto-Odiel; C3, Piedras. Impacted marshland (I): Doñana ditions relative to tidal regime, wave action, coastal drift currents and fluvial dynamics were similar to those characterizing the impacted marshland (Rodríguez-Ramírez et al. 2008).

Fish sampling was performed in the intertidal creeks. These relatively short and shallow branched creeks run through Sarcocornia, Arthrocnemum and Spartina stands and are characterized by sandy-mud substratum. The intertidal creeks in the control locations were chosen from a set of possible sites that had habitat characteristics similar to those of the impacted area, always with nonrestricted tidal dynamics. Sampling was conducted 4 times (June, July, August and September 2011; T1 to T4, respectively) using the same fish sampling protocol. In each marshland, 3 intertidal creeks (hereafter referred to as sites) were sampled, with 4 replicates at each site, for a total of 192 units of observation.

In order to reduce the bias on small-sized fishes (Malavasi et al. 2004), sampling was performed using sets (=replicates) of 3 fyke nets with different mesh sizes ( 1 for each mesh size: $0.1,0.5$ and $1.0 \mathrm{~cm}$ ) and 2 minnow traps, and each set was placed covering an area of about $100 \mathrm{~m}^{2}$. In order to minimize the confounding effects of variations in tidal stage and environmental conditions between each location and to standardize the sampling regime, all sites were sampled at high tide and with similar tide coefficients for each survey.

Adult and sub-adult fish were anaesthetised using clove oil, counted and weighed (total weight, $\pm 0.1 \mathrm{~g}$ ) in situ, and then released. Juvenile individuals were sacrificed with an overdose of clove oil, fixed in formaldehyde $(10 \%)$ and brought to the laboratory for taxonomic identification. All fish were identified to the species level except Carassius spp. due the difficulty in discerning between 2 introduced cryptic species present in the study area (Ribeiro et al. 2015). All species were classified into guilds according to the estuarine use functional group (EUFG), feeding mode functional group (FMFG) and reproductive mode functional group (RMFG; see Table 1). To allocate different species into functional guilds, we used the information published in Franco et al. (2008) and additional previous works (Arias \& Drake 1985, Costa et al. 1992, Banarescu \& Paepke 2002, Blanco et al. 2004, Veiga et al. 2006, Elliott et al. 2007, Froese undisturbed marshlands where environmental con- 
\& Pauly 2014). When the published information was not enough to allocate species into specific guilds, we consulted expert opinion (P. Nieto pers. comm, P. Drake pers. comm, F. Baldó pers. comm). Due the opportunistic nature and ontogenic variation of feeding habits in fishes, some species were assigned to more than 1 FMFG. Species biomass and abundance were standardized to biomass per unit effort (BPUE, $\mathrm{g} \mathrm{set}^{-1}$ in $24 \mathrm{~h}$ ) and catch per unit effort (CPUE, number of ind. set ${ }^{-1}$ in $24 \mathrm{~h}$ ).

\section{Multivariate data analysis}

A distance-based permutational multivariate analysis of variance (PERMANOVA, Anderson 2001) was used to test for differences in I versus Cs (I-vs$\mathrm{Cs})$. The model consisted of 3 factors: time ( $\mathrm{T}, 4 \mathrm{lev}-$ els, random), location (L, 4 levels, random, crossed), site $(\mathrm{S}(\mathrm{L}), 3$ levels, random, nested in $\mathrm{L})$ with $\mathrm{n}=4$ replicates (see above for details).

As we sampled only a single putatively impacted location, the design is asymmetrical (Underwood 1994, Wiens \& Parker 1995, Glasby 1997). Therefore, for the analysis, the location term was partitioned into 2 portions: I-vs-Cs and Cs. S(L) was similarly divided into $\mathrm{S}(\mathrm{I})$ and $\mathrm{S}(\mathrm{Cs})$. Finally, the residual variation (Res) was divided in the residual variability among replicates within I (Res I) and within Cs (Res $\mathrm{Cs})$. Denominators of $F$-ratios were identified according to the logic for the asymmetrical analysis described by Underwood (1992) and Glasby (1997) (see also Terlizzi et al. 2005). Tests for terms that involved specific sources of variation for I or Cs were constructed using the natural denominator for that term (Terlizzi et al. 2005). The analysis was performed based on Bray-Curtis dissimilarities of untransformed taxon abundance and biomass of the ecological guilds. Each term in the analysis was tested using 4999 random permutations (Anderson \& Ter Braak 2003). The p-values were obtained using a Monte Carlo random sample from the asymptotic permutation distribution (Anderson \& Robinson 2003). Results were interpreted using a significance level of $\alpha=0.1$ in light of the precautionary principle.

Differences in assemblage structure between I-vsCs were portrayed by non-metric multi-dimensional scaling (nMDS) ordination of the $\mathrm{T} \times \mathrm{I}$-vs-Cs centroids based on untransformed data of species abundance and biomass of the functional groups (EUFG, FMFG, RMFG). A permutational test of multivariate dispersion (PERMDISP; Anderson 2006) was employed to investigate possible effects of the impact on small-scale (among replicates) spatial heterogeneity of assemblages (Bevilacqua et al. 2012). The analysis was performed separately for each time and based on Jaccard's distance, and terms were tested with 999 permutations.

A SIMPER analysis (Clarke 1993) on untransformed data was performed separately for each time of sampling in order to identify species and ecological guilds that contributed most to dissimilarities between I and Cs locations. The dissimilarity average contribution of each species or functional guild and the ratio of dissimilarity average to standard deviation were calculated to identify consistent species or guilds distinguishing groups. High values in this ratio indicate that a species or guild is consistent in making a difference across the majority of samples in the comparison of I-vs-Cs.

All analyses were done using the computer program DISTLM (Anderson \& Ter Braak 2003, Anderson 2004) and PRIMER 6 software (Clarke \& Gorley 2006).

\section{Univariate analysis}

ANOVA was performed to test the same hypothesis of no difference between I-vs-Cs for species richness, total abundance and total biomass. Prior the analyses, Cochran's $C$-test was used to check for heterogeneity of variance, and data were transformed (ln + 1) if required. The analysis was done using the GAD package (Sandrini-Neto \& Camargo 2012) available for CRAN.

\section{RESULTS}

\section{Fish assemblage composition and structure}

Overall, we collected a total of 25 species belonging to 15 families (54 216 individuals; Table 1). Since the sampling effort was the same in all marshlands and the catches and biomass were standardized, we calculated the total abundance and biomass (in terms of relative abundance and biomass) to explore differences between the marshlands. The total abundance (CPUE, number of individuals) was 122884 at I, 3729 at $\mathrm{C} 1,2007$ at $\mathrm{C} 2$ and 2173 at $\mathrm{C} 3$. The total biomass (BPUE, g) was 1294775 at I, 17591 at C1, 4155 at C2 and 6796 at $\mathrm{C} 3$ (Table 1). At the I location, 11 fish species were detected, of which 4 were exotic (Cyprinus carpio, Carassius spp., Fundulus heteroclitus and Gambusia holbrooki). These 4 exotic species ac- 
Table 1. Fish species, ecological guilds, relative abundance (catch per unit effort, CPUE: ind. set ${ }^{-1}$ in 24 h) and relative biomass (biomass per unit effort, BPUE: $\mathrm{g} \mathrm{set}^{-1}$ in $24 \mathrm{~h}$ in brackets) collected at the sampled locations. EUFG: estuarine use functional group (C: catadromous, ES: estuarine, F: freshwater, MM: marine migrant, MS marine straggler); FMFG: feeding mode functional group (OV: omnivore, HZ: hyperbenthivore/zooplanktivore, Bmi: microbenthivore, HP: hyperbenthivore/piscivore, DV: detritivore, Bma: macrobenthivore); RMFG: reproductive mode functional group (Op: oviparous with pelagic eggs, Ov: oviparous with adhesive eggs, Og: oviparous guarder, V: viviparous, Ob: oviparous with benthic eggs, Os: oviparous shelterer), -: species not found at this site

\begin{tabular}{|c|c|c|c|c|c|c|c|c|}
\hline \multirow[t]{2}{*}{ Family } & \multirow[t]{2}{*}{ Species } & \multirow[t]{2}{*}{ EUFG } & \multirow[t]{2}{*}{ FMFG } & \multirow[t]{2}{*}{ RMFG } & \multicolumn{4}{|c|}{ Relative abundance (relative biomass) } \\
\hline & & & & & $\begin{array}{l}\text { Guadiana } \\
\text { (Control 1) }\end{array}$ & $\begin{array}{l}\text { Tinto-Odiel } \\
\text { (Control 2) }\end{array}$ & $\begin{array}{l}\text { Piedras } \\
\text { (Control 3) }\end{array}$ & $\begin{array}{c}\text { Doñana } \\
\text { (Impacted) }\end{array}$ \\
\hline Anguillidae & Anguilla anguilla & $\mathrm{C}$ & OV & Op & $86(3744)$ & - & 7 (931) & 1009 (47021) \\
\hline Atherinidae & Atherina boyeri & ES & HZ & $\mathrm{Ov}$ & $68(23)$ & $123(79)$ & $57(36)$ & $16(16)$ \\
\hline Batrachoididae & Halobatrachus didactylus & ES & Bmi, HP & Og & - & - & $4(126)$ & - \\
\hline Blenniidae & Salaria pavo & ES & OV & Og & $9(49)$ & $5(16)$ & $2(15)$ & - \\
\hline \multirow[t]{2}{*}{ Cyprinidae } & Carassius spp. & $\mathrm{F}$ & $\mathrm{OV}$ & $\mathrm{Ov}$ & - & - & - & $25183(364907)$ \\
\hline & Cyprinus carpio & $\mathrm{F}$ & OV & $\mathrm{Ov}$ & - & - & - & $39821(801551)$ \\
\hline Cyprinodontidae & Aphanius baeticus & ES & Bmi & $\mathrm{Ov}$ & - & - & - & $283(50)$ \\
\hline Fundulidae & Fundulus heteroclitus & ES & $\mathrm{OV}$ & $\mathrm{Ov}$ & 1160 (1219) & $7(3)$ & - & $13541(33346)$ \\
\hline \multirow[t]{3}{*}{ Gobiidae } & Gobius niger & $\mathrm{ES}$ & Bmi, HP & Og & $3(1)$ & - & $19(68)$ & - \\
\hline & Gobius paganellus & ES & Bmi, HP & $\mathrm{Og}$ & - & $33(157)$ & $8(24)$ & - \\
\hline & Pomatoschistus microps & ES & $\mathrm{Bmi}$ & Og & 994 (119) & $1282(291)$ & $1919(512)$ & $39(8)$ \\
\hline \multirow[t]{2}{*}{ Moronidae } & Dicentrarchus labrax & $\mathrm{MM}$ & $\mathrm{HZ}, \mathrm{HP}$ & Op & 56 (4689) & $17(873)$ & 5 (1921) & - \\
\hline & Dicentrarchus punctatus & MM & $\mathrm{HZ}, \mathrm{HP}$ & Op & $35(802)$ & $86(1622)$ & - & - \\
\hline \multirow[t]{3}{*}{ Mugilidae } & Chelon labrosus & MM & DV & Op & $416(4002)$ & $389(384)$ & $15(434)$ & $554(18146)$ \\
\hline & Liza ramada & MM & DV & Op & $5(2371)$ & - & $5(4)$ & 48 (13826) \\
\hline & Mugil cephalus & $\mathrm{MM}$ & DV & Op & - & - & - & 31 (9038) \\
\hline Poeciliidae & Gambusia holbrooki & ES & $\mathrm{OV}$ & $\mathrm{V}$ & $872(174)$ & - & - & $42358(6866)$ \\
\hline Scorpaenidae & Scorpaena porcus & ES & Bma, HP & $\mathrm{Ob}$ & - & - & $10(889)$ & - \\
\hline \multirow[t]{2}{*}{ Soleidae } & Dicologlossa cuneata & MM & Bmi, Bma & Op & - & $3(1)$ & - & - \\
\hline & Solea senegalensis & $\mathrm{MM}$ & Bmi, Bma & $\mathrm{Ob}$ & $10(266)$ & $6(8)$ & $35(643)$ & - \\
\hline \multirow[t]{4}{*}{ Sparidae } & Diplodus annularis & MS & OV & $\mathrm{Ob}$ & - & $28(32)$ & $7(302)$ & - \\
\hline & Diplodus bellottii & MM & OV & $\mathrm{Ob}$ & - & $22(517)$ & $65(526)$ & - \\
\hline & Diplodus sargus & MS & OV & $\mathrm{Ob}$ & - & $4(162)$ & - & - \\
\hline & Sparus aurata & MS & Bmi, Bma & $\mathrm{Ob}$ & $3(127)$ & $2(9)$ & $9(360)$ & - \\
\hline Syngnathidae & Syngnathus abaster & ES & Bmi & Os & $11(5)$ & - & $4(4)$ & - \\
\hline $\begin{array}{l}\text { Total abundance } \\
\text { (total biomass) }\end{array}$ & & & & & $\begin{array}{c}3729 \\
(17591)\end{array}$ & $\begin{array}{c}2007 \\
(4155)\end{array}$ & $\begin{array}{l}2173 \\
(6799)\end{array}$ & $\begin{array}{c}122884 \\
(1294775)\end{array}$ \\
\hline
\end{tabular}

counted for about $98 \%$ of the total abundance and $93 \%$ of the total biomass. At C1, 14 fish species were collected, and the most abundant species were $F$. heteroclitus and Pomatoschistus microps. Fish richness at $\mathrm{C} 2$ and $\mathrm{C} 3$ was 14 and 16 species, respectively. P. microps was also dominant in terms of abundance at $\mathrm{C} 2$ and C3. At I, G. holbrooki was the dominant species in abundance, together with $C$. carpio.

Considering all of the studied marshlands, the dominant EUFGs were estuarine (11 species) and marine migrants (8 species). In terms of the feeding habits of fishes, omnivores (9 species) and microbenthivores (9 species) were the FMFGs mostly present in the captures, and oviparous fish with pelagic $(7$ species) and benthonic (6 species) eggs comprised the dominant RMFGs.
The marine migrant guild accounted for 69,83 and $56 \%$ of the total biomass at C1, C2 and C 3 respectively, while most of the biomass detected in the Doñana marshland (I) was attributed to the freshwater guild ( $90 \%$ of total biomass). The only catadromous species captured in the study was Anguilla anguilla, which had a biomass of 21,14 and $4 \%$ of the captured fish at C1, C2 and I, respectively. The marine straggler guild was scarce at $\mathrm{Cs}$ and absent from I. At Cs, the FMFG biomass was composed of a diverse group of fish, and most of the guilds described were present, while at the I location, $96.8 \%$ of the biomass was composed of the omnivorous guild. Macrobenthivore and hyperbenthivore/ piscivore guilds were only present at Cs. Finally, with regard to the RMFG, the oviparous guild with pelagic eggs accounted for highest biomass at all control 
locations (89\% in $\mathrm{C} 1 ; 69 \%$ in $\mathrm{C} 2 ; 48 \%$ in $\mathrm{C} 3$ ). In contrast, oviparous with adhesive eggs were the main guild at I (93\%).

\section{Multivariate analysis}

We found a significant effect of tidal restriction in modifying the structure of fish assemblages (species composition and relative abundance) at I-vs-Cs (Table 2). The same pattern of difference between Ivs-Cs was detected by analysing biomass of the functional groups (EUFG, FMFG, RMFG; Tables 3-5). In all cases, spatial-temporal dynamics of fish assemblages significantly differed at I-vs-Cs (Tables 2-5). The post hoc tests carried out separately for each time of sampling indicated that the overall differences between I-vs-Cs were consistent through time (Tables 2-5).

The centroids between I-vs-Cs were clearly separated, forming 2 clear groups (I and Cs), and temporal variability of the fish assemblage at I was higher with respect to Cs (Fig. 2). Sites in both Cs and I had a high spatial and temporal variability at the scale of sites, but I had a higher small-scale homogeneity of assemblages (Tables 2-5). Such patterns of reduced small-scale patchiness at I with respect to Cs were confirmed by the results of PERMDISP on the whole fish assemblage, which highlighted a higher homogeneity in species composition at I ( $p<0.001$ in all cases; Fig. 3).

C. carpio was an important species differentiating assemblages at I from those at Cs at almost all sampling times, and especially during $\mathrm{T} 1$ and $\mathrm{T} 2$ (Table 6). At these sampling times, Carassius spp. were also important, and the same species contributed to dissimilarities between I-vs-Cs in T3 and T4. The most important species contributing to differences between I and Cs was G. holbrooki in T3 and $F$. heteroclitus in T4. P. microps contributed to differentiating I-vs-Cs in T3 and T4. Freshwater and estuarine guilds were the most important guilds in differentiating assemblages inhabiting Cs from those at I at all sampling times. However, biomass of marine migrants and catadromous guilds also contributed to differences in T3 and T4. For FMFG, the omnivorous guild accounted for more than $90 \%$ of dissimilarities between I and Cs in T1 and T2, but in T3 and T4, detritivores were also important. Regarding RMFG, oviparous with adhesive eggs was the most impor-

Table 2. Permutational ANOVA (PERMANOVA) based on Bray-Curtis dissimilarities (untransformed data) of species abundance (25 species). Each test was performed using 4999 permutations of appropriate units. p-values for post hoc pairwise tests were obtained using 4999 Monte Carlo samples from the asymptotic permutation distribution. T: time of sampling, L: location, S: site, I: impacted marshland; Cs: control marshlands; Res: residuals. MS denominator selected according to Underwood (1992) and Terlizzi et al. (2005). Only tests for terms relevant to the hypothesis are reported ${ }^{*} p<0.05,{ }^{* *} p<0.005$

\begin{tabular}{|c|c|c|c|c|c|c|}
\hline Source of variation & df & $\mathrm{SS}$ & Pseudo- $F$ & $\mathrm{p}$ & MS denom & Permutable units \\
\hline $\mathrm{T}$ & 3 & 28517.87 & & & & \\
\hline L & 3 & 158313.17 & & & & \\
\hline I-vs-Cs & 1 & 103801.80 & & & & \\
\hline $\mathrm{Cs}$ & 2 & 54511.37 & & & & \\
\hline $\mathrm{S}(\mathrm{L})$ & 8 & 109431.63 & & & & \\
\hline $\mathrm{S}(\mathrm{I})$ & 2 & 20903.72 & & & & \\
\hline $\mathrm{S}(\mathrm{Cs})$ & 6 & 88527.91 & & & & \\
\hline $\mathrm{T} \times \mathrm{L}$ & 9 & 74086.87 & & & & \\
\hline $\mathrm{T} \times \mathrm{I}-\mathrm{vs}-\mathrm{Cs}$ & 3 & 49804.86 & 3.71 & 0.0002 & $\mathrm{~T} \times \mathrm{S}(\mathrm{L})$ & $48 \mathrm{~T} \times \mathrm{S}(\mathrm{L})$ cells \\
\hline $\mathrm{T} \times \mathrm{Cs}$ & 6 & 24282.01 & 1.03 & 0.4128 & $\mathrm{~T} \times \mathrm{S}(\mathrm{Cs})$ & $36 \mathrm{~T} \times \mathrm{S}(\mathrm{Cs})$ cells \\
\hline $\mathrm{T} \times \mathrm{S}(\mathrm{L})$ & 24 & 107245.17 & 2.14 & 0.0002 & Residual & 192 raw data units \\
\hline $\mathrm{T} \times \mathrm{S}(\mathrm{I})$ & 6 & 36899.03 & 6.15 & 0.0002 & Residual I & 48 raw data units \\
\hline $\mathrm{T} \times \mathrm{S}(\mathrm{Cs})$ & 18 & 70346.15 & 1.59 & 0.0002 & Residual Cs & 144 raw data units \\
\hline Residual & 144 & 300836.58 & & & & \\
\hline Res I & 36 & 35983.03 & & & & \\
\hline Res Cs & 108 & 264853.55 & & & & \\
\hline \multirow[t]{2}{*}{ Total } & 191 & 778431.30 & & & & \\
\hline & & $\begin{array}{c}\text { T1 } \\
\text { Pseudo-F }\end{array}$ & $\begin{array}{c}\text { T2 } \\
\text { Pseudo-F }\end{array}$ & $\begin{array}{c}\text { T3 } \\
\text { Pseudo- } F\end{array}$ & $\begin{array}{c}\text { T4 } \\
\text { Pseudo-F }\end{array}$ & \\
\hline I-vs-Cs & & $3.98^{*}$ & $4.06^{* *}$ & $3.66^{*}$ & $2.85^{*}$ & \\
\hline
\end{tabular}


tant guild at all sampling times. Oviparous with pelagic eggs were also important in $\mathrm{T} 3$ and $\mathrm{T} 4$, and viviparous was important in discriminating between I and Cs in T3. It is worth noting the larger variations through time in the abundance of species and biomass of guilds at I compared to Cs, which again indicated a higher temporal variability at the impacted location.

Table 3. PERMANOVA based on Bray-Curtis dissimilarities (untransformed data) of the estuarine use functional group (EUFG) biomass data. Other details as in Table $2{ }_{i}{ }^{*} \mathrm{p}<0.005,{ }^{* *} \mathrm{p}<0.001$

\begin{tabular}{|c|c|c|c|c|c|c|}
\hline Source of variation & $\mathrm{df}$ & SS & Pseudo- $F$ & $\mathrm{p}$ & MS denom & Permutable units \\
\hline $\mathrm{T}$ & 3 & 30562.46 & & & & \\
\hline $\mathrm{L}$ & 3 & 136332.69 & & & & \\
\hline I-vs-Cs & 1 & 113885.31 & & & & \\
\hline $\mathrm{Cs}$ & 2 & 22447.37 & & & & \\
\hline $\mathrm{S}(\mathrm{L})$ & 8 & 72386.09 & & & & \\
\hline $\mathrm{S}(\mathrm{I})$ & 2 & 18764.28 & & & & \\
\hline $\mathrm{S}(\mathrm{Cs})$ & 6 & 53621.81 & & & & \\
\hline $\mathrm{T} \times \mathrm{L}$ & 9 & 70578.47 & & & & \\
\hline $\mathrm{T} \times \mathrm{I}$-vs-Cs & 3 & 47798.94 & 4.17 & 0.0002 & $\mathrm{~T} \times \mathrm{Cs}$ & $16 \mathrm{~T} \times \mathrm{Cs}$ cells \\
\hline $\mathrm{T} \times \mathrm{Cs}$ & 6 & 22779.54 & 1.30 & 0.1490 & $\mathrm{~T} \times \mathrm{S}(\mathrm{Cs})$ & $36 \mathrm{~T} \times \mathrm{S}(\mathrm{Cs})$ cells \\
\hline $\mathrm{T} \times \mathrm{S}(\mathrm{L})$ & 24 & 86856.85 & 1.54 & 0.0002 & Residual & 192 raw data units \\
\hline $\mathrm{T} \times \mathrm{S}(\mathrm{I})$ & 6 & 34234.69 & 7.50 & 0.0002 & Residual I & 48 raw data units \\
\hline $\mathrm{T} \times \mathrm{S}(\mathrm{Cs})$ & 18 & 52622.15 & 1.01 & 0.4418 & Residual Cs & 144 raw data units \\
\hline Residual & 144 & 339017.83 & & & & \\
\hline Res I & 36 & 27382.46 & & & & \\
\hline Res Cs & 108 & 311635.36 & & & & \\
\hline \multirow[t]{2}{*}{ Total } & 191 & 735734.39 & & & & \\
\hline & & $\begin{array}{c}\text { T1 } \\
\text { Pseudo- } F\end{array}$ & $\begin{array}{c}\text { T2 } \\
\text { Pseudo- } F\end{array}$ & $\begin{array}{c}\text { T3 } \\
\text { Pseudo- } F\end{array}$ & $\begin{array}{c}\text { T4 } \\
\text { Pseudo-F }\end{array}$ & \\
\hline I-vs-Cs & & $6.12^{*}$ & $8.06^{* *}$ & $6.85^{*}$ & $12.62^{* *}$ & \\
\hline
\end{tabular}

Table 4. PERMANOVA based on Bray-Curtis dissimilarities (untransformed data) of the feeding mode functional group (FMFG) biomass data. Other details as in Table $2{ }_{i}{ }^{*} \mathrm{p}<0.05$

\begin{tabular}{|c|c|c|c|c|c|c|}
\hline Source of variation & $\mathrm{df}$ & SS & Pseudo- $F$ & $\mathrm{p}$ & MS denom & Permutable units \\
\hline $\mathrm{T}$ & 3 & 22186.54 & & & & \\
\hline $\mathrm{L}$ & 3 & 156812.07 & & & & \\
\hline I-vs-Cs & 1 & 116761.64 & & & & \\
\hline $\mathrm{Cs}$ & 2 & 40050.43 & & & & \\
\hline $\mathrm{S}(\mathrm{L})$ & 8 & 88402.64 & & & & \\
\hline $\mathrm{S}(\mathrm{I})$ & 2 & 11356.84 & & & & \\
\hline $\mathrm{S}(\mathrm{Cs})$ & 6 & 77045.80 & & & & \\
\hline $\mathrm{T} \times \mathrm{L}$ & 9 & 69550.86 & & & & \\
\hline $\mathrm{T} \times \mathrm{I}$-vs-Cs & 3 & 42280.95 & 3.12 & 0.0002 & $\mathrm{~T} \times \mathrm{Cs}$ & $16 \mathrm{~T} \times$ Cs cells \\
\hline $\mathrm{T} \times \mathrm{Cs}$ & 6 & 27269.91 & 1.17 & 0.2176 & $\mathrm{~T} \times \mathrm{S}(\mathrm{Cs})$ & $36 \mathrm{~T} \times \mathrm{S}(\mathrm{Cs})$ cells \\
\hline $\mathrm{T} \times \mathrm{S}(\mathrm{L})$ & 24 & 98366.29 & 1.68 & 0.0002 & Residual & 192 raw data units \\
\hline $\mathrm{T} \times \mathrm{S}(\mathrm{I})$ & 6 & 28664.01 & 7.18 & 0.0002 & Residual I & 48 raw data units \\
\hline $\mathrm{T} \times \mathrm{S}(\mathrm{Cs})$ & 18 & 69702.29 & 1.28 & 0.0166 & Residual Cs & 144 raw data units \\
\hline Residual & 144 & 351580.98 & & & & \\
\hline Res I & 36 & 23960.27 & & & & \\
\hline Res Cs & 108 & 327620.71 & & & & \\
\hline \multirow[t]{2}{*}{ Total } & 191 & 786899.39 & & & & \\
\hline & & $\begin{array}{c}\text { T1 } \\
\text { Pseudo-F }\end{array}$ & $\begin{array}{c}\text { T2 } \\
\text { Pseudo- } F\end{array}$ & $\begin{array}{c}\text { T3 } \\
\text { Pseudo- } F\end{array}$ & $\begin{array}{c}\text { T4 } \\
\text { Pseudo-F }\end{array}$ & \\
\hline I-vs-Cs & & $4.56^{*}$ & $4.26^{*}$ & $5.07^{*}$ & $5.23^{*}$ & \\
\hline
\end{tabular}


Table 5. PERMANOVA based on Bray-Curtis dissimilarities (untransformed data) of the reproductive mode functional group (RMFG) biomass data. Other details as in Table $2{ }^{*}{ }^{*} \mathrm{p}<0.05,{ }^{* *} \mathrm{p}<0.005$

\begin{tabular}{|c|c|c|c|c|c|c|}
\hline Source of variation & df & SS & Pseudo- $F$ & $\mathrm{p}$ & MS denom & Permutable units \\
\hline $\mathrm{T}$ & 3 & 34534.47 & & & & \\
\hline $\mathrm{L}$ & 3 & 77795.79 & & & & \\
\hline I-vs-Cs & 1 & 27698.87 & & & & \\
\hline $\mathrm{Cs}$ & 2 & 53669.68 & & & & \\
\hline $\mathrm{S}(\mathrm{L})$ & 8 & 68643.59 & & & & \\
\hline $\mathrm{S}(\mathrm{I})$ & 2 & 11793.29 & & & & \\
\hline $\mathrm{S}(\mathrm{Cs})$ & 6 & 60615.00 & & & & \\
\hline $\mathrm{T} \times \mathrm{L}$ & 9 & 71635.19 & & & & \\
\hline $\mathrm{T} \times \mathrm{I}-\mathrm{vs}-\mathrm{Cs}$ & 3 & 35471.15 & 1.68 & 0.0072 & $\mathrm{~T} \times \mathrm{S}(\mathrm{L})$ & $48 \mathrm{~T} \times \mathrm{S}(\mathrm{L})$ cells \\
\hline $\mathrm{T} \times \mathrm{Cs}$ & 6 & 15180.07 & 0.97 & 0.5048 & $\mathrm{~T} \times \mathrm{S}(\mathrm{Cs})$ & $36 \mathrm{~T} \times \mathrm{S}(\mathrm{Cs})$ cells \\
\hline $\mathrm{T} \times \mathrm{S}(\mathrm{L})$ & 24 & 168620.65 & 2.32 & 0.0002 & Residual & 192 raw data units \\
\hline $\mathrm{T} \times \mathrm{S}(\mathrm{I})$ & 6 & 29974.61 & 7.40 & 0.0002 & Residual I & 48 raw data units \\
\hline $\mathrm{T} \times \mathrm{S}(\mathrm{Cs})$ & 18 & 46836.76 & 1.32 & 0.0452 & Residual Cs & 144 raw data units \\
\hline Residual & 144 & 436752.27 & & & & \\
\hline Res I & 36 & 24304.71 & & & & \\
\hline Res Cs & 108 & 212693.69 & & & & \\
\hline \multirow[t]{2}{*}{ Total } & 191 & 857981.96 & & & & \\
\hline & & $\begin{array}{c}\text { T1 } \\
\text { Pseudo-F }\end{array}$ & $\begin{array}{c}\text { T2 } \\
\text { Pseudo- } F\end{array}$ & $\begin{array}{c}\text { T3 } \\
\text { Pseudo- } F\end{array}$ & $\begin{array}{c}\text { T4 } \\
\text { Pseudo-F }\end{array}$ & \\
\hline I-vs-Cs & & $4.79^{* *}$ & $3.90^{*}$ & $3.02^{*}$ & $6.45^{* *}$ & \\
\hline
\end{tabular}
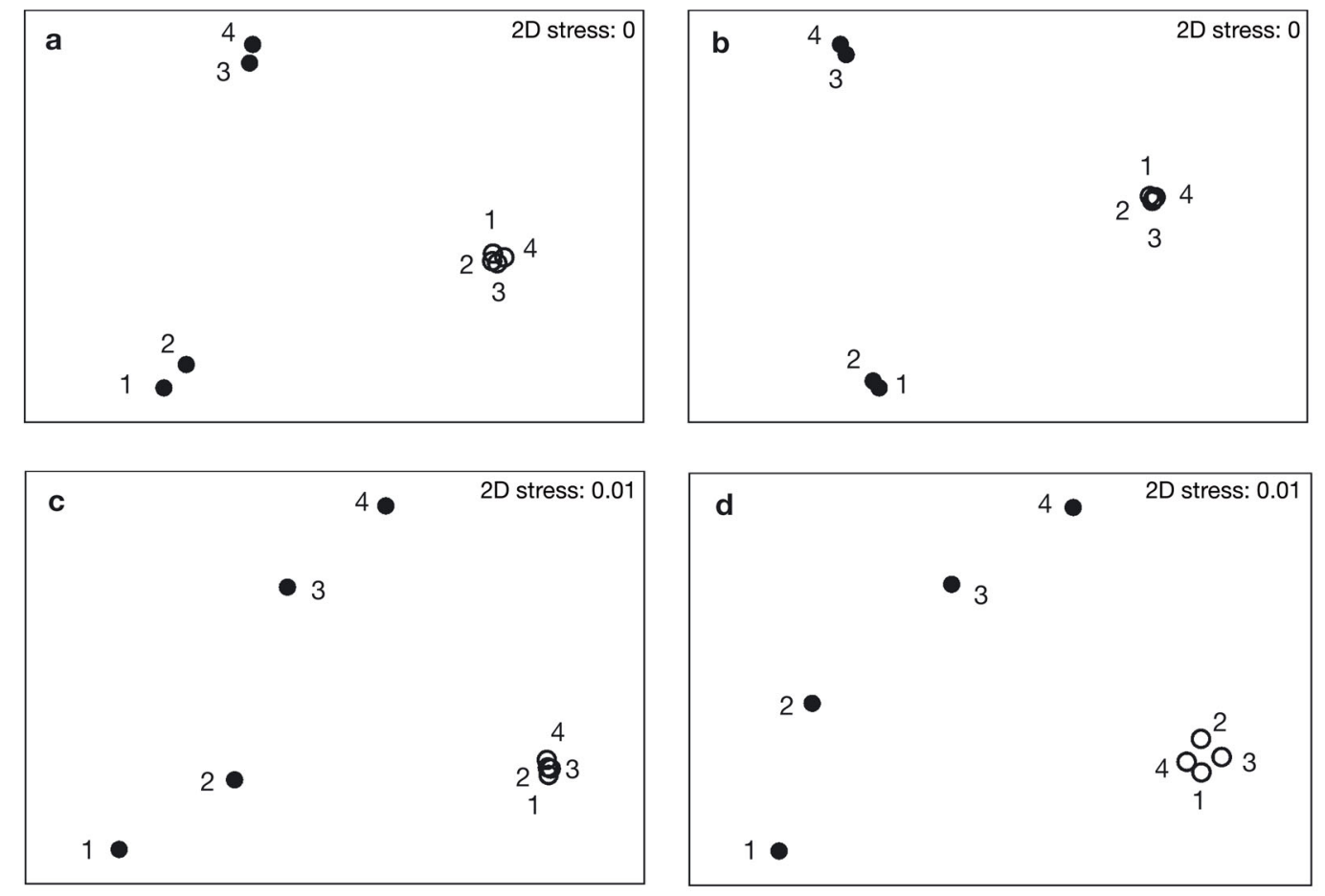

Fig. 2. Non-metric multidimensional scaling ordination (nMDS) on the basis of the Bray-Curtis dissimilarity measure of sampling time $\times$ impacted vs. control sites $(\mathrm{T} \times \mathrm{I}$-vs-Cs) centroids based on (a) abundance of taxa, (b) biomass of estuarine use functional groups, (c) biomass of feeding mode functional groups and (d) biomass of reproductive mode functional groups. The numbers represent the sampling times (T1-T4). Black circles represent the impacted marshland, and white circles represent the control locations 


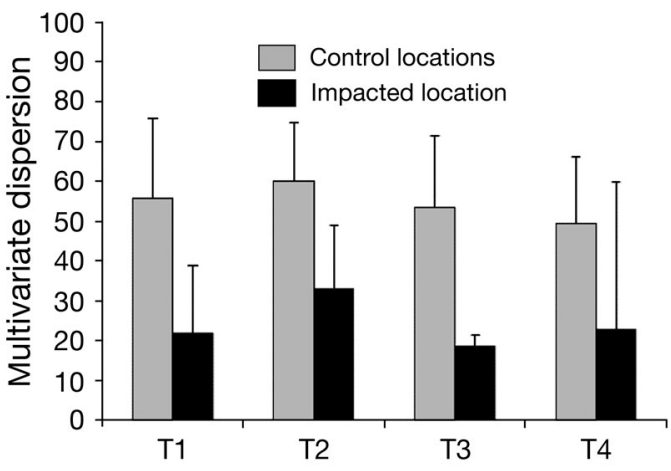

Fig. 3. Mean $( \pm \mathrm{SD})$ of the multivariate dispersion around impacted vs. control sites (I-vs-Cs) centroids based on Jaccard's distance (see 'Materials and methods' for details) for all sampling times (T1-T4)

\section{Univariate analysis}

All investigated variables (richness, abundance, biomass) showed large temporal and spatial variation within locations (Table 7). Species richness did not differ between I and Cs (Table 7, Fig. 4). In contrast, abundance was significantly higher at I compared to Cs in all sampling times. A significant effect of restriction was also detected on fish biomass (Table 7), which reached significantly higher values in I with respect to Cs at all sampling times (Fig. 4).

\section{DISCUSSION}

Our findings indicate that tidal restriction in marshlands may significantly affect the structural and functional characteristics of fish assemblages, and may increase their temporal fluctuations with respect to control areas. The dominance of freshwater and estuarine guilds at the impacted marshland (Doñana) may be explained by the degradation of the tidal habitat as a consequence of the reduced influx of seawater, which likely enhanced the influence of fresh water (Kroon \& Ansell 2006). MorenoValcárcel et al. (2013) found that the 4 species responsible for the differences between the impacted locations and controls (Cyprinus carpio, Carassius spp., Fundulus heteroclitus and Gambusia holbrooki), were dominant in terms of biomass and abundance in the area closer to the estuary in the Doñana marshland.

Although ecological guild structures should be similar in the same biogeographical areas (Elliott et al. 2007), the guild structure detected in the impacted marshland was dominated by freshwater and es- tuarine species; this is unusual compared to other Atlantic estuaries, where the assemblages are composed mainly of marine migrants and catadromous and estuarine species (Mathieson et al. 2000, Elliott et al. 2007, Selleslagh et al. 2009). On the other hand, the prominence of the estuarine guild differentiating between groups could be an example of the 'estuarine quality paradox', which describes the difficulty in differentiating between natural conditions and human-induced changes in estuaries due to the similarities between organisms and assemblages inhabiting both systems (Dauvin 2007, Elliott \& Quintino 2007). Thus in our study, the co-dominance of estuarine species (highly tolerant to salinity changes) in the assemblages of the impacted marshland does not necessarily reflect a good conservation status of the estuary. Strengthening this idea, most of the fish present in Doñana are invasive species, demonstrating a higher vulnerability to invasion of such degraded ecosystems (Moyle \& Light 1996, Kennard et al. 2005). FMFGs and RMFGs also differed between I and Cs, with generalist omnivores and species with adhesive eggs mainly characterizing the impacted marshland, while control sites showed a diverse composition that was not dominated by a single functional guild. Functional guilds that were more affected by the habitat modification were those that depend on specific habitat requirements, such as micro- and macrobenthivores, while generalist guilds (omnivores) proliferated, taking advantage of the environmental change. The total abundance and biomass at the impacted marshland were 3 to 4 orders of magnitude higher than in the control marshlands, whereas species richness was similar. These high values of abundance and biomass may be related to the effects of the wall and sluice gates blocking the water and the fish inside the marsh. It is worth noting that only a few invasive species at the impacted location accounted for these large differences in productivity.

Our results indicate that tidal restriction in marshlands degrades habitat via the loss of connectivity, providing homogeneous environmental conditions suitable for non-native species. The heterogeneity in assemblage composition was significantly lower in the impacted marshland than at the control sites, suggesting an effect of tidal restriction in decreasing $\beta$-diversity of fish assemblages. This process can be seen as a biotic homogenization of the marshland. Biotic homogenization (including genetic, taxonomic and functional aspects) concerns the process by which native communities are gradually replaced by widespread, cosmopolitan and non-native communi- 


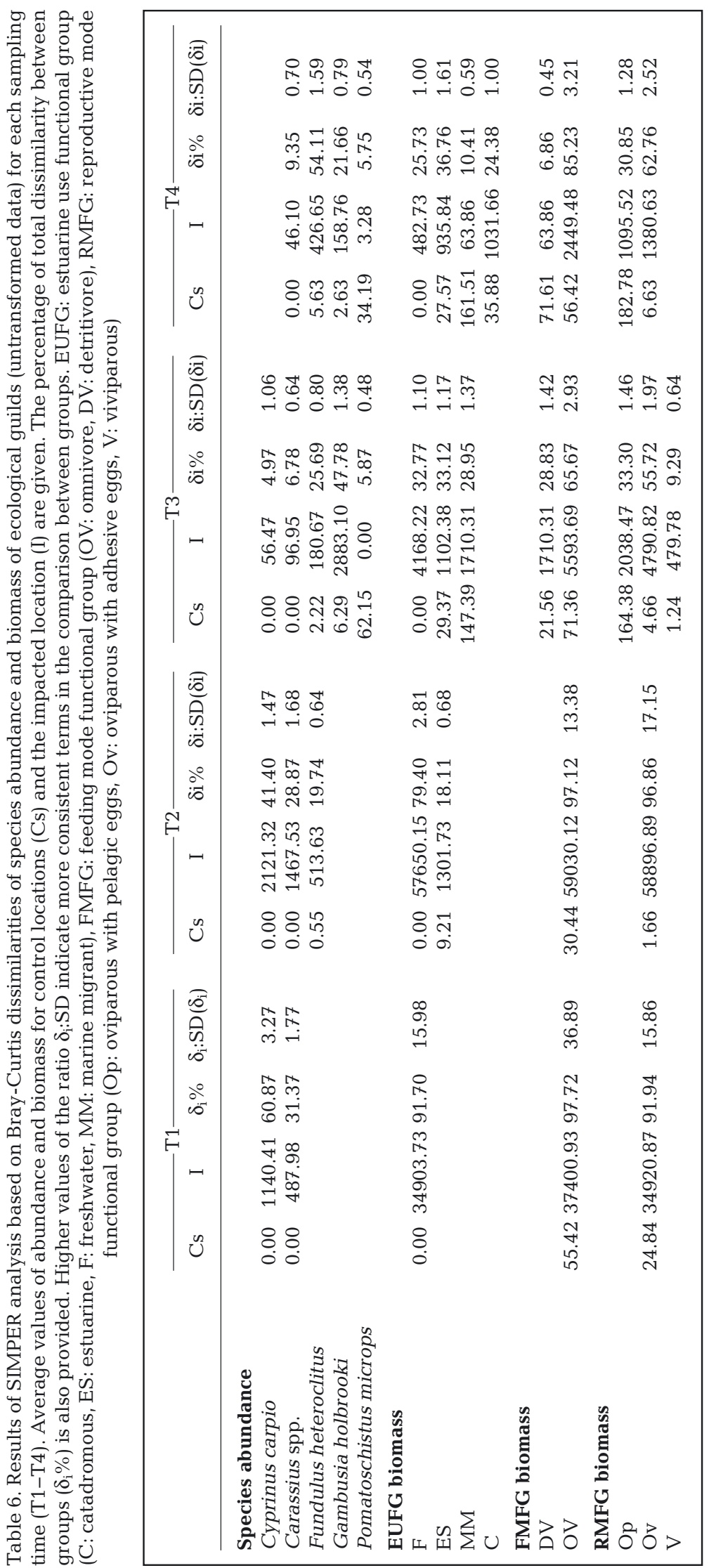

ties as a result of anthropogenic modifications of the environment (Olden et al. 2004). While taxonomic homogenization has generally received more attention, genetic and functional homogenization still remain poorly studied (Olden 2006). Specifically, the process of functional homogenization is defined as an increase in the functional similarity of the biota over time because of the establishment of species with similar roles in the ecosystem and the loss of species possessing unique functional roles. In other words, functional homogenization generally results in the loss of specialist species and an increase in generalist species (Olden 2006, Clavel et al. 2011), as we observed in the restricted marshland, where fish assemblages were dominated by invasive omnivorous and estuarine fishes.

Homogenization of assemblages is considered one of the general outcomes of human impacts (Balata et al. 2007, Donohue et al. 2009, Claudet \& Fraschetti 2010), although disturbance, depending on its nature (e.g. type, intensity, frequency, duration) and whether it is natural or anthropogenic, could determine contrasting patterns of either increased or decreased heterogeneity (Warwick \& Clarke 1993, Thrush et al. 1998, Bevilacqua et al. 2012). Interestingly, the homogeneity of fish assemblages inhabiting the impacted marshland in our study was accompanied by lower temporal stability with respect to control locations. Other studies have found increased temporal variability in assemblages exposed to multiple sources of human disturbance, although such patterns were related to increased smallscale patchiness and, therefore, to a potential reduction of connectivity among patches (e.g. Fraschetti et al. 2012, 2013). High connectivity, in fact, could promote local resilience, because effects of local perturbations might be eliminated quickly through subsidiary inputs from the broader system (Scheffer et al. 2012). The reduced connectivity to the marine environment, and the ensuing increased isolation from marine fish assemblages, as a consequence of tidal 
Table 7. Summary of asymmetrical ANOVA on taxa richness, total abundance and total biomass. T: time of sampling; L: location, S: site, I: impacted marshland; Cs: control marshlands; Res: residuals. ${ }^{*} \mathrm{p}<0.1,{ }^{* *} \mathrm{p}<0.01,{ }^{* * *} \mathrm{p}<0.001$. Only tests for terms relevant to the hypothesis are reported

\begin{tabular}{|c|c|c|c|c|c|c|c|}
\hline \multirow[t]{2}{*}{ Source of variation } & \multirow[t]{2}{*}{$\mathrm{df}$} & \multicolumn{2}{|c|}{ Richness } & \multicolumn{2}{|c|}{ Abundance } & \multicolumn{2}{|c|}{ Biomass } \\
\hline & & MS & $F$ & MS & $F$ & MS & $F$ \\
\hline $\mathrm{T}$ & 3 & 0.40 & & 1.23 & & 3.05 & \\
\hline $\mathrm{L}$ & 3 & 3.32 & & 201.13 & & 339.32 & \\
\hline I-vs-Cs & 1 & 2.75 & 4.10 & 195.93 & $37.67^{*}$ & 312.10 & \\
\hline $\mathrm{Cs}$ & 2 & 0.56 & 0.67 & 5.20 & 0.65 & 27.22 & \\
\hline $\mathrm{S}(\mathrm{L})$ & 8 & 0.67 & $3.57^{* *}$ & 6.44 & $3.79^{* *}$ & 9.97 & \\
\hline $\mathrm{S}(\mathrm{I})$ & 2 & 0.00 & 0.00 & 0.00 & 0.00 & 0.00 & \\
\hline $\mathrm{S}(\mathrm{Cs})$ & 6 & 0.84 & $3.77^{*}$ & 7.96 & $5.98^{* *}$ & 12.87 & \\
\hline $\mathrm{T} \times \mathrm{L}$ & 9 & 0.23 & 1.21 & 5.88 & $3.46^{* *}$ & 10.69 & \\
\hline $\mathrm{T} \times \mathrm{I}-\mathrm{vs}-\mathrm{Cs}$ & 3 & 0.11 & 0.58 & 3.42 & 2.01 & 9.11 & $2.85^{*}$ \\
\hline $\mathrm{T} \times \mathrm{Cs}$ & 6 & 0.13 & 0.59 & 2.46 & 1.85 & 1.58 & 0.64 \\
\hline $\mathrm{T} \times \mathrm{S}(\mathrm{L})$ & 24 & 0.19 & $2.11^{* *}$ & 1.70 & $2.04^{* *}$ & 3.20 & $1.78^{*}$ \\
\hline $\mathrm{T} \times \mathrm{S}(\mathrm{I})$ & 6 & 0.00 & 0.00 & 0.37 & 0.00 & 0.75 & 0.00 \\
\hline $\mathrm{T} \times \mathrm{S}(\mathrm{Cs})$ & 18 & 0.22 & $2.23^{* *}$ & 1.33 & 1.45 & 2.45 & 1.07 \\
\hline Residual & 144 & 0.09 & & 0.83 & & 1.80 & \\
\hline Res I & 36 & 0.00 & & 0.00 & & 0.00 & \\
\hline Res Cs & 108 & 0.10 & & 0.92 & & 2.28 & \\
\hline \multirow[t]{2}{*}{ Cochran test } & & & \multicolumn{2}{|c|}{$C=0.11$} & \multicolumn{2}{|c|}{$C=0.09$} \\
\hline & & \multicolumn{2}{|c|}{$p>0.05$} & \multicolumn{2}{|c|}{$\mathrm{p}=0.05$} & \multicolumn{2}{|c|}{$\mathrm{p}>0.05$} \\
\hline
\end{tabular}

restriction could explain the increased instability of fish assemblages in the impacted marshland. Moreover, functional homogenization, which was also associated with compositional homogenization and lower total species richness, could have hampered the ability of assemblages in the impacted marshland to absorb environmental fluctuations, increasing their vulnerability to environmental changes (Micheli \& Halpern 2005, Hewitt et al. 2010, Clavel et al. 2011).

This study highlights the importance of structuring a synoptic approach, accounting for both structure and functioning of fish assemblages, in the assessment of the effects of tidal restriction in marshlands. These effects may modify the temporal and spatial variability of the fish assemblages and induce changes in fish diversity. Such findings will provide baseline information about the consequences of marshland alterations on fish communities, which is still largely lacking in the European environmental context, and may be valuable for future research, management and restoration plans.

Fig. 4. Mean $( \pm \mathrm{SD}, \mathrm{n}=12)$ of species richness, total abundance and total biomass at each of the 4 sampling times (T1-T4). LN: natural (Naperian) logarithm; CPUE: catch per unit effort (i.e. number of individuals per set of traps in $24 \mathrm{~h}$; BPUE: biomass per unit effort (i.e. $g$ per set of traps in $24 \mathrm{~h}$; see 'Materials and methods' for details)

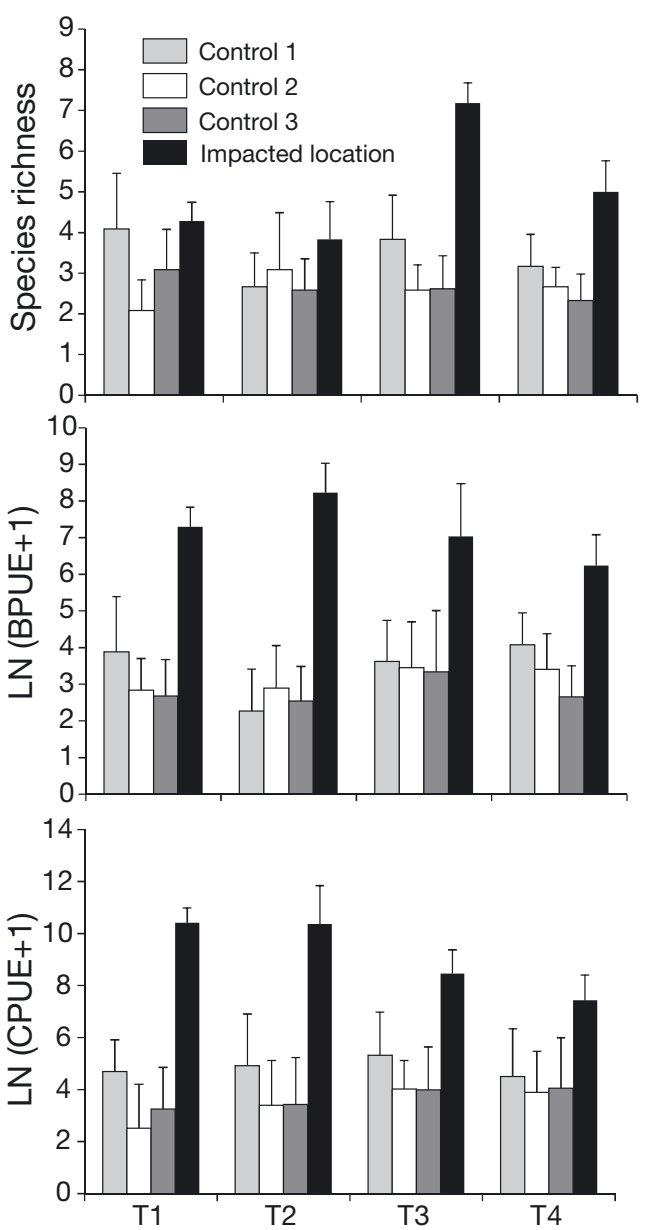


Acknowledgements. This research was supported by the Environmental Regional Government within the Project 'Los peces como organismos indicadores de la eliminación y permeabilización de la Montaña del Río'. We thank Manuel Ruiz and Juan Luis Fernández de la Rosa for help with the surveys, and Rocío Astasio and the Estación Biológica de Doñana staff for their kind assistance.

\section{LITERATURE CITED}

Anderson MJ (2001) Permutation tests for univariate or multivariate analysis of variance and regression. Can J Fish Aquat Sci 58:626-639

Anderson MJ (2004) DISTLM v.5: a FORTRAN computer program to calculate a distance-based multivariate analysis for a linear model. Department of Statistics, University of Auckland, Auckland

Anderson MJ (2006) Distance-based tests for homogeneity of multivariate dispersions. Biometrics 62:245-253

Anderson MJ, Robinson J (2003) Generalized discriminant analysis based on distances. Aust N Z J Stat 45:301-318

> Anderson MJ, Ter Braak CJF (2003) Permutation tests for multi-factorial analysis of variance. J Stat Comput Simul 73:85-113

Archambault P, Banwell K, Underwood AJ (2001) Temporal variation in the structure of intertidal assemblages following the removal of sewage. Mar Ecol Prog Ser 222:51-62

Arias AM, Drake P (1985) Estructura de la población y régimen alimentario de Anguilla anguilla L., 1758 (Osteichthyes, Anguillidae), en los esteros de San Fernándo (Cádiz). Investig Pesq 49:475-491

Balata D, Piazzi L, Benedetti-Cecchi L (2007) Sediment disturbance and loss of beta diversity on subtidal rocky reefs. Ecology 88:2455-2461

Banarescu PM, Paepke HJ (eds) (2002) The freshwater fishes of Europe. Vol 5/III, Cyprinidae 2, Part III: Carassius to Cyprinus, Gasterosteides. AULAVerlag $\mathrm{GmbH}$, Wiebelsheim, p 85-179

Bayán-Jardín BJ (2006) The paths of water in the marshes: changes in the hydrological network. In: Marín-Cabrera C, García-Novo F (eds) Doñana water and biosphere. UNESCOMaB (Man and Biosphere Programme), Junta de Andalucía, Consejería de Medio Ambiente, Madrid, p 151-155

> Benedetti-Cecchi L, Osio GC (2007) Replication and mitigation of effects of confounding variables in environmental impact assessment: effect of marinas on rocky-shore assemblages. Mar Ecol Prog Ser 334:21-35

- Bevilacqua S, Plicanti A, Sandulli R, Terlizzi A (2012) Measuring more of $\beta$-diversity: quantifying patterns of variation in assemblage heterogeneity. An insight from marine benthic assemblages. Ecol Indic 18:140-148

Bevilacqua S, Terlizzi A, Mistri M, Munari C (2015) New frameworks for species surrogacy in monitoring highly variable coastal ecosystems: applying the BestAgg approach to Mediterranean coastal lagoons. Ecol Indic 52:207-218

Blanco S, Romo S, Villena MJ (2004) Experimental study on the diet of mosquitofish (Gambusia holbrooki) under different ecological conditions in a shallow lake. Int Rev Hydrobiol 89:250-262

Boys CA, Williams RJ (2012) Succession of fish and crustacean assemblages following reinstatement of tidal flow in a temperate coastal wetland. Ecol Eng 49:221-232
Bryant JC, Chabreck RH (1998) Effects of impoundment on vertical accretion of coastal marsh. Estuaries 21:416-422

Clarke KR (1993) Non-parametric multivariate analyses of changes in community structure. Aust J Ecol 18:117-143

Clarke KR, Gorley RN (2006) PRIMER v6: user manual/tutorial. PRIMER-E, Plymouth

> Claudet J, Fraschetti F (2010) Human-driven impacts on marine habitats: a regional meta-analysis in the Mediterranean Sea. Biol Conserv 143:2195-2206

$>$ Clavel J, Julliard R, Devictor V (2011) Worldwide decline of specialist species: toward a global functional homogenization? Front Ecol Environ 9:222-228

Cognetti G, Maltagliati F (2008) Perspectives on the ecological assessment of transitional waters. Mar Pollut Bull 56: 607-608

Costa MJ, Cabral HN, Drake P, Economou AN and others (1992) Recruitment and production of commercial species in estuaries. In: Elliott $\mathrm{M}$, Hemingway KL (eds) Fishes in estuaries. Blackwell Science, Oxford, p 54-104

> Couvillion BR, Beck H (2013) Marsh collapse thresholds for coastal Louisiana estimated using elevation and vegetation index data. J Coast Res 63:58-67

Crain CM, Gedan KB, Dionne M (2009) Tidal restrictions and mosquito ditching in New England marshes. In: Silliman BR, Grosholz ED, Bertness MD (eds) Human impacts on salt marshes: a global perspective. University of California Press, Oakland, CA, p 149-171

> Dauvin JC (2007) Paradox of estuarine quality: benthic indicators and indices, consensus or debate for the future. Mar Pollut Bull 55:271-281

Davy AJ, Bakker JP, Figueroa ME (2009) Human modification of European salt marshes. In: Silliman BR, Grosholz ED, Bertness MD (eds) Human impacts on salt marshes: a global perspective. University of California Press, p 311-377

Dibble KL, Meyerson LA (2012) Tidal flushing restores the physiological condition of fish residing in degraded salt marshes. PLoS ONE 7:e46161

Díez-Minguito $\mathrm{M}$, Baquerizo A, Ortega-Sánchez $\mathrm{M}$, Navarro G, Losada MA (2012) Tide transformation in the Guadalquivir estuary (SW Spain) and process-based zonation. J Geophys Res 117:c03019, doi: 10.1029/ 2011JC007344

Donohue I, Jackson AL, Pusch MT, Irvine K (2009) Nutrient enrichment homogenizes lake benthic assemblages at local and regional scales. Ecology 90:3470-3477

Eberhardt AL, Burdick DM, Dionne M (2011) The effects of road culverts on nekton in New England salt marshes: implications for tidal restoration. Restor Ecol 19:776-785

- Elliott M, Quintino V (2007) The estuarine quality paradox, environmental homeostasis and the difficulty of detecting anthropogenic stress in naturally stressed areas. Mar Pollut Bull 54:640-645

Elliott M, Whitfield AK, Potter IC, Blaber SJM, Cyrus DP, Nordlie FG, Harrison TD (2007) The guild approach to categorizing estuarine fish assemblages: a global review. Fish Fish 8:241-268

Fernández-Delgado C (2005) Conservation management of a European natural area. Doñana National Park, Spain. In: Groom MJ, Meffe GK, Carroll CR (eds) Principles of conservation biology, 3rd edn. Sinauer Associates, Sunderland, MA, p 536-543

- Franco A, Elliott M, Franzoi P, Torricelli P (2008) Life strategies of fishes in European estuaries: the functional guild approach. Mar Ecol Prog Ser 354:219-228 
Fraschetti S, Bevilacqua S, Guarnieri G, Terlizzi A (2012) Idiosyncratic effects of protection in a remote marine reserve. Mar Ecol Prog Ser 466:21-34

Fraschetti S, Guarnieri G, Bevilacqua S, Terlizzi A, Boero F (2013) Protection enhances community and habitat stability: evidence from a Mediterranean Marine Protected Area. PLoS ONE 8:e81838

Froese R, Pauly D (eds) (2014) FishBase. www.fishbase.org

Gedan KB, Silliman BR, Bertness MD (2009) Centuries of human-driven change in salt marsh ecosystems. Annu Rev Mar Sci 1:117-141

Glasby TM (1997) Analysing data from post-impact studies using asymmetrical analyses of variance: a case study of epibiota on marinas. Austral Ecol 22:448-459

Harrington RW Jr, Harrington ES (1982) Effects on fishes and their forage organisms of impounding a Florida salt marsh to prevent breeding by salt marsh mosquitoes. Bull Mar Sci 32:523-525

Hewitt J, Thrush SF, Lohrer A, Townsend M (2010) A latent threat to biodiversity: consequences of small-scale heterogeneity loss. Biodivers Conserv 19:1315-1323

Kennard MJ, Arthington AH, Pusey BJ, Harch BD (2005) Are alien fish a reliable indicator of river health? Freshw Biol 50:174-193

Kennish MJ (2001) Coastal salt marsh systems in the U.S.: a review of anthropogenic impacts. J Coast Res 17: 731-748

> Kirwan ML, Megonigal JP (2013) Tidal wetland stability in the face of human impacts and sea-level rise. Nature 504: 53-60

> Kroon FJ, Ansell DH (2006) A comparison of species assemblages between drainage systems with and without floodgates: implications for coastal floodplain management. Can J Fish Aquat Sci 63:2400-2417

> Lardicci C, Rossi F, Maltagliati F (1999) Detection of thermal pollution: variability of benthic communities at two different spatial scales in an area influenced by a coastal power station. Mar Pollut Bull 38:296-303

Lobry J, Mourand L, Rochard E, Elie P (2003) Structure of the Gironde estuarine fish assemblages: a comparison of European estuaries perspective. Aquat Living Resour 16: 47-58

> Maes J, Van Damme S, Meire P, Ollevier F (2004) Statistical modeling of seasonal and environmental influences on the population dynamics of an estuarine fish community. Mar Biol 145:1033-1042

- Malavasi S, Fiorin R, Franco A, Franzoi P, Granzotto A, Riccato F, Mainardi D (2004) Fish assemblages of Venice Lagoon shallow waters: an analysis based on species, families and functional guilds. J Mar Syst 51: 19-31

Mathieson S, Cattrijsse A, Costa MJ, Drake P, Elliott M, Gardner J, Marchand J (2000) Fish assemblages of European tidal marshes: a comparison based on species, families and functional guilds. Mar Ecol Prog Ser 204: 225-242

McGovern JC, Wenner CA (1990) Seasonal recruitment of larval and juvenile fishes into impounded and nonimpounded marshes. Wetlands 10:203-221

> Menéndez M, Hernandez O, Comin FA (2002) Spatial distribution and ecophysiological characteristics of macrophytes in a Mediterranean coastal lagoon. Estuar Coast Shelf Sci 55:403-413

Micheli F, Halpern BS (2005) Low functional redundancy in coastal marine assemblages. Ecol Lett 8:391-400
Mora JW, Burdick DM (2013) The impact of man-made earthen barriers on the physical structure of New England tidal marshes (USA). Wetl Ecol Manag 21:387-398

- Moreno-Valcárcel R, Oliva-Paterna FJ, Arribas C, Fernández-Delgado C (2013) Fish composition and assemblage in the anthropogenic-modified tidally-restricted Doñana (Spain) marshlands. Estuar Coast Shelf Sci 119:54-63

Moyle PB, Light T (1996) Fish invasions in California: Do abiotic factors determine success? Ecology 77:1666-1670

> Nicolas D, Lobry J, Lepage M, Sautour B and others (2010) Fish under influence: a macroecological analysis of relations between fish species richness and environmental gradients among European tidal estuaries. Estuar Coast Shelf Sci 86:137-147

Olden JD (2006) Biotic homogenization: a new research agenda for conservation biogeography. J Biogeogr 33: 2027-2039

> Olden JD, Poff NL, Douglas MR, Douglas ME, Fausch KD (2004) Ecological and evolutionary consequences of biotic homogenization. Trends Ecol Evol 19:18-24

Pérez-Domínguez R, Maci S, Courrat A, Lepage M and others (2012) Current developments on fish-based indices to assess ecological-quality status of estuaries and lagoons. Ecol Indic 23:34-45

Pollard DA, Hannan JC (1994) The ecological effects of structural flood mitigation works on fish habitats and fish communities in the lower Clarence River system of south-eastern Australia. Estuaries 17:427-461

Portnoy JW (1991) Summer oxygen depletion in a diked New England estuary. Estuaries 14:122-129

Portnoy JW, Giblin AE (1997) Effects of historic tidal restrictions on salt marsh sediment chemistry. Biogeochemistry 36:275-303

Queiroz NC, Lima FP, Ribeiro PA, Pereira SG, Santos AM (2006) Using asymmetrical designs for environmental impact assessment of unplanned disturbances. Hydrobiologia 555:223-227

> Ribeiro F, Rylková K, Moreno-Valcárcel R, Carrapato C, Kalous L (2015) Prussian carp Carassius gibelio: a silent invader arriving to the Iberian Peninsula. Aquat Ecol 49: 99-104

> Ritter AF, Wasson K, Lonhart SI, Preisler RK and others (2008) Ecological signatures of anthropogenically altered tidal exchange in estuarine ecosystems. Estuaries Coasts 31:554-571

Rodríguez-Ramírez A, Morales JA, Delgado I, Cantano M (2008) The impact of man on the morphodynamics of the Huelva coast (SW Spain). J Iberian Geol 34:73-108

Roman CT, Niering WA, Warren RS (1984) Salt marsh vegetation change in response to tidal restriction. Environ Manag 8:141-149

Sandrini-Neto L, Camargo MG (2012) GAD: an R package for ANOVA designs from general principles. $\mathrm{R}$ package version 1.1.1. http://CRAN.R-project.org/package=GAD

> Scheffer M, Carpenter SR, Lenton TM, Bascompte J and others (2012) Anticipating critical transitions. Science 338: 344-348

Selleslagh J, Amara R, Laffargue P, Lesourd S, Lepage M, Girardin M (2009) Fish composition and assemblage structure in three Eastern English Channel macrotidal estuaries: a comparison with other French estuaries. Estuar Coast Shelf Sci 81:149-159

> Tagliapietra D, Sigovini M, Ghirardini AV (2009) A review of terms and definitions to categorise estuaries, lagoons and associated environments. Mar Freshw Res 60:497-509 
Terlizzi A, Benedetti-Cecchi L, Bevilacqua S, Fraschetti S, Guidetti P, Anderson MJ (2005) Multivariate and univariate asymmetrical analyses in environmental impact assessment: a case study of Mediterranean subtidal sessile assemblages. Mar Ecol Prog Ser 289: $27-42$

Thrush SF, Hewitt JE, Cummings VJ, Dayton PK and others (1998) Disturbance of the marine benthic habitat by commercial fishing: impacts at the scale of the fishery. Ecol Appl 8:866-879

Underwood AJ (1991) Beyond BACI: experimental designs for detecting human environmental impacts on temporal variations in national populations. Aust J Mar Freshw Res 42:569-587

Underwood AJ (1992) Beyond BACI: the detection of environmental impacts on populations in the real, but variable, world. J Exp Mar Biol Ecol 161:145-178

Editorial responsibility: Jana Davis, Annapolis, Maryland, USA
Underwood AJ (1994) On beyond BACI: sampling designs that might reliably detect environmental disturbances. Ecol Appl 4:3-15

Veiga P, Vieira L, Bexiga C, Sá R, Erzini K (2006) Structure and temporal variations of fish assemblages of the Castro Marim salt marsh, southern Portugal. Estuar Coast Shelf Sci 70:27-38

Warwick RM, Clarke KR (1993) Increased variability as a symptom of stress in marine communities. J Exp Mar Biol Ecol 172:215-226

Whitfield AK, Elliott M (2002) Fishes as indicators of environmental and ecological changes within estuaries: a review of progress and some suggestions for the future. J Fish Biol 61:229-250

Wiens JA, Parker KR (1995) Analyzing the effects of accidental environmental impacts: approaches and assumptions. Ecol Appl 5:1069-1083

Submitted: May 7, 2015; Accepted: December 1, 2015

Proofs received from author(s): January 25, 2016 